\title{
Talking Right, Walking Wrong: Global Environmental Negotiations and Unsustainable Environmental Consumption
}

\author{
${ }^{1}$ Luke Amadi, ${ }^{2}$ Prince Igwe, ${ }^{3}$ Mina Ogbanga \\ ${ }^{1,2}$ Dapartment of Political Science and Administrative Studies, University of Port Harcourt, Nigeria \\ ${ }^{3}$ Department of Sociology, University of Port Harcourt, Nigeria
}

\begin{abstract}
The persistent problems of deleterious environmental consumption by the industrialized societies despite global environmental negotiations bring to bear the need for a critical reappraisal of novel trends in environmental sustainability and ecological discourse. The paper interrogates the plausibility of the negotiations in providing a cutting edge sustainable development agenda. Using tools of analysis from secondary data, a relational content analysis (RCA) methodology is deployed to operationalize global environmental negotiations and summits between the periods 1970 to 2015 to identify salient gaps with respect to implementation. Findings from the study suggest that most of the negotiations and resolutions are not legally bidding which vitiate the level of commitment of the high income countries. For instance, the argument from Agenda 21-that all stakeholders should adopt some level of sustainable environmental consumption has been minimally enforced by the industrialized societies. The study made some policy recommendations that suggest the urgency of a shift from negotiation to enforcement.
\end{abstract}

Keywords: Environmental Negotiations, Unsustainable Consumption, the Global North, Sustainable Development.

\section{INTRODUCTION}

Recent studies suggest that environmental and ecological issues have not been given adequate attention in global development discourse (Adibe, 1994). Contemporary global trends reveal that environmental negotiation which is a conscious engagement in environmental discourse to resolve differences and incompatibility through collective consensus, compromise or agreement has increasingly become a common collective ground to address global environmental threats.

A critical appraisal of these negotiations is an important research agenda which seeks for broader elucidation of the salient issues associated with environmental challenges at post environmental negotiations.

Overshadowed in the Cold War era by the struggle between capitalism and Western democracy on the one hand and communism and socialism on the other, was the challenge of superficial attention to environmental issues as increasing environmental threats and disasters gave rise to early scholarly concern and research on the environment.

Rachael Carson (1962) captured the crux of this environmental levity in the 1960s in her seminal book the Silent Spring published in the United States which reawakened human consciousness on the dangers of desecrating the earth with pesticides and pollution of the environment through the persistent use of Dichloro-Diphenyl Trichloroethane (DDT). Lynn White (1967) adopted the concept of ecology to explore unsustainable environmental resource consumption. Similarly, a number of environmental challenges faced by the poor societies of Africa, Asia and Latin America were given minimal attention.

Earlier conception of development centered on the ability to tame nature or harness its abundant resources while societies of the global South who relied on pristine natural environment were termed primitive and backward ( Adibe, 1994:496).

In the late 1960s a group of scientists called the Club of Rome gathered and rephrased some formulations through scholarly research, to which some environmental consensus were built which gave rise to the publication in 1972 of the findings of their research namely; The Limits to Growth: 
This had a common institutional core that established some of the subsequent global environmental consciousness. Yet this awareness may not be final as it became increasingly important to convene a global forum for environmental negotiation.

Environmental negotiation has a long history since at least the 20th century. Such earlier global negotiations included the 1972 convention on protection of the World Cultural and Natural Heritage adopted in Paris France and Convention on the Prevention of Marine Pollution by Dumping of Wastes and other Substances held in London, United Kingdom and Mexico in 1972 , perhaps one of the foremost approximation to the clamor for a wider global environmental negotiation was the 1972 UN Stockholm conference on Environment which provided the Stockholm Declaration, that reported growing evidence of man-made harm in many regions of the earth: dangerous levels of pollution in water, air, earth and living beings; major and undesirable disturbances to the ecological balance of the biosphere; destruction and depletion of irreplaceable resources; and gross deficiencies harmful to the physical, mental and social health of man, in the man-made environment, particularly in the living and working environment .

To strengthen and institutionalize the ideals of global environmental development within the mainstream development discourse was the establishment of the United Nations Environment Programme (UNEP) in 1975.This gave significant boost to global environmental awareness.

In 1987, the Brundtland Commission report, Our Common Future, gave greater impetus to environmental consciousness as it defined sustainable development as development that meets the needs of the present generation without compromising the ability of the future generations to meet their own needs (WCSD, 1987).

In 1988, at Toronto Canada was the World Conference on the Changing Atmosphere. The negotiation provided the well -known "Toronto Target" which aims to reduce carbon dioxide emissions 20 per cent by 2005. This was followed by increasing concern on climate issues such as uncertainties of climate change and its associated vulnerability challenges ,thus in 1988, the Intergovernmental Panel on Climate Change(IPCC) was set up primarily to explore and provide more scientific understanding of global climate issues ( FCCC,1993).

In the 1990s, increasing environmental threats came to the fore, as the Cold War came to an end with resurgence of new wars and local conflicts in the global South and the growing unsustainable environmental consumption by the high income countries of the North as globalization became a key development strand. Thus the challenges of industrialization and sustainable development have been enormous (Hobson, 2003; Davidson and Hatt, et al; 2005; Schor, 2005).For instance deleterious environmental activities such as industrial pollution emerged through technological innovations and manufacturing (Hagedorn, et al; 1980; Schor, 2005). This was accompanied with environmental insecurity, pressure, displacement and migration (Homer Dixon, 1991; Adibe, 1994; Klare, 1993; Shurke, 1996).

Ashri Suhrke (1996) re-echoes some key aspects of environmental pressure affecting security of the state; (1)environmental degradation can cause health hazards or jeopardize the economic livelihood of a significant part of the population;(2)intensified competition for declining or degraded resources can create conflicts within or among States: these in turn can generate regional instabilities that affect nations further afield;(3)environmental degradation may force people to migrate, thereby creating conflict over scarce resources in the receiving areas; and (4)the existentialist argument advanced by a school of environmentalists and ecological economists to the effect that an environmental resource has an intrinsic value regardless of its being consumed(even in the form of being seen), and hence its loss is a matter of security (Shurke,1996:115).

Homer Dixon and the Toronto Group identified similar environmental pressure arising from resource scarcity (Homer Dixon, 1991) and the increasing vulnerability of the poor societies. Richard Worzel (1994:176) argued that the biggest problem that those concerned with the environment have had is the indifference or outright hostility of consumers and corporations, who do not want to hear a message that tells them: you cannot go on doing what you have been doing.

Robert Goodland points to five key pieces of evidence that the earth was at the limits of growth: Human Biomass Appropriation, Global Warming, Ozone Shield Rupture, Land Degradation, Decrease in Biodiversity (Goodland, 1992:7). 
Perhaps one of the most seminal blue print on sustainable development emerged in the 1992 UNCED conference in Rio de Janeiro, Brazil, which provided agenda 21 plan of action for implementation of sustainable environmental consumption. Five years later was the Rio plus five involving a group of experts to review the progress made so far, their report showed dismal performance on environmental awareness, care and consciousness.

In the 2000s, at the adoption of the Millennium Development Goals (MDGs) there was persistent global environmental insecurity notably the intensity of storms such as hurricanes, tsunamis, earth quakes, floods and droughts. For instance Hurricane Sandy was a recent storm which impacted 24 of the 50 United States, causing about US $\$ 65$ billion damages.

Global corruption has also been linked to unsustainable environmental consumption of the high income societies. In a 2014 report, Transparency International identified the cost of climate induced damage. The cost in Cuba is put at US\$2 billion, while the Bahamas it stood at about US\$700 million. In the Philippines, there was Typhoon Haiyan which took about 6,200 lives and about US\$878 million in damage (Transparency International,2014).

Beyond environmental disasters there have been conflicts, arms race and chemical weapons proliferation, a number of conflict and environmental scholars advocate for more global negotiations and conventions (Davenport 2006; Tharkur,2006),specifically incorporating the societies of the global South.

Deborah Saunders Davenport, had argued on global environmental negotiations and U.S. interests. She addressed the questions surrounding the successes and failures of some global environmental problems. Cognizant of the unequal infrastructure of the international system she argued that compromise among states in critical particularly the strategic interest and willingness of "the lead state" (Davenport,2006).

On the other hand, in a study; on the chemical weapons convention: implementation, challenges and opportunities , Indian social scientist, Ramesh Tharkur (2006)demonstrated the need for opportunities for negotiation and implementation of global Chemical Weapons Convention . Thus, environmental negotiations at once becomes a paradigm to salvage what Paul Collier (2010)termed "the plundered Planet", as he analyzed the effects of natural resource exploitation on humanity and how such global environmental problems could be solved such as violent conflict, global warming etc.

This research argues that more than ever, environmental negotiation comes close circle to salvage the deleterious effects of human activities on the environment, however what has remained minimal is enforcement.

The article argues for a shift from negotiation to enforcement, which is the central problem of this research as it contends that despite the global summits and negotiations, the environment has been deleteriously consumed as most of the negotiations are not legally bidding. This has tainted human and non -human resources. The article turns to materials and methods.

\section{MAterials AND Methods}

This paper is a relational content analysis (RCA) which explores salient global summits and environmental negotiations between 1970 to 2012. Environmentalists have evolved a number of explanations and methodologies for the study of the global environmental summits and negotiations. One of the most influential methodologies in studying this interaction is the content analysis approach.

Content analysis examines and summarizes composition of a document or a written material the aim is to understand what the material is saying Lasswell (1948).

According to Holsti (1969:14) "any technique for making inferences by objectively and systematically identifying specified characteristics of messages" constitutes the primary concern of content analysis. It aims at objective analysis rather than implicit impressions.

In particular it helps in this research to understand the contents and resolutions associated with global environmental negotiations (Krippendorff, 1980; Weber, 1990; Stemler and Bebell ,1998). 


\subsection{Data for Content Analysis}

A fundamental relevance of the content analysis is its quantitative and qualitative utility in research. Content analysis primarily derives its data sources from both primary and secondary sources. The primary sources of data include interviews and its transcription, analysis of focused group discussions (FGDs), and research questionnaires. While secondary data sources include texts written and verbal (Krippendorff, 1998).

For our purpose, the research focuses on secondary data sources to examine issues raised and resolutions adopted in the selected global environmental conventions. Content analysis is important in understanding interpretive exploration of existing literature and existing studies. It adopts a multi disciplinary approach and brings together political, environmental, geographical, economic and ecological perspectives etc to understand the interconnections between society and the environment. This involves understanding the dynamics of environmental processes such as environmental disasters, degradation, environmental consumption patterns which have political, economic or social implications and in particular how this affects humans, plants animals and the ecology.

Content Analysis approach provides inductive, deductive as well as chronological analysis of socioeconomic and ecological phenomenon. This is important in this study as it provides lucid genealogical mapping of selected environmental negotiations. Since its emergence in scholarly research content analysis has also been used to study organizations, social systems, institutions, conflicts, social interactions, governments, network of relationships in the environment etc(Lasswell,1948; Berelson, 1952; Holsti,1969; Krippendorff, 1980; 1998;Weber, 1990; Stemler and Bebell ,1998).

Environmental negotiation as used in this paper encompasses global environmental related summits and conventions. It encompasses a number of resolutions which aim at understanding issues associated with environmental challenges.

The following purposively selected environmental negotiations will be examined namely, the 1972 UN Conference on the Environment which held in Stockholm, United Nations Conference on Environment and Development in 1992 in Rio de Janeiro, World Summit on Sustainable Development (WSSD) in Johannesburg, South Africa in 2002, and the Rio +20 environmental summit of 2012.

These are important being core and most widely participated global environmental negotiations which involved a wider spectrum of world leaders from both the industrialized and developing nations. The aim is to clearly identify the level of commitment and compliance or other wise of the affluent countries to global environmental negotiations as well as the level of enforcement and bidding of the resolutions reached at the negotiations on parties and signatories to the negotiations. What follows is an exploration of the global negotiations by world leaders classified in this research as "talking right" .This will be substantially linked to a broader elucidation of the practicalities of the provisions of the negotiations and effects of deleterious effects of the unsustainable environmental consumption patterns of the high income countries and its effects on the environment at post environmental negotiations (walking wrong).

\section{TAlking Right: Global EnVironmental Negotiations}

Several global environmental summits and conventions have provided robust and veritable negotiations among experts, world leaders and similar stakeholders in tackling global environmental challenges. Both as analytical and theoretical apparatus, negotiation on any issue, individually or collectively, understandably aims to achieve the best possible outcome irrespective of varying positions.

Core principles such as fair hearing, mutual understanding and benefits, are some of the useful considerations both in local, regional and global negotiations. However, this article focuses on global environmental negotiations which fall within the international strand of negotiation. Global environmental negotiations are landmark innovations linked to the efforts of world leaders at institutionalizing international standards for environmental use for sustainable development. It includes amelioration of unsustainable environmental consumption and evolving a common tools that promote ecological justice, resource accountability and equity. There have been a number of such environmental negotiations notably the 1972 Convention on The Protection of the World Cultural and Natural Heritage adopted in Paris France, Convention on the Prevention of Marine Pollution by 
Dumping of Wastes and other Substances held in London, United Kingdom and Mexico in 1972,The UN Stockholm conference on the Human Environment, 1972, Convention on International Trade in Engendered Species of Wild Fauna and Flora(CITES) adopted in Washington DC ,USA 1973, International Convention for the Prevention of Pollution from Ships in London United kingdom 1973, Convention on the Pollution of Military or any other Hostile use of Environmental Modification held in Geneva 1977, Protocol on International Convention for the Prevention of Pollution from Ships adopted in 1973, Convention on the Conservation of Migrating Species of Wild Animals in Bonn Germany 1979,Brundtland Commission Report of 1987, UN Conference on Environment and Development (UNCED) 1992, the post- Rio + Five Summit, -The Johannesburg Plan of Implementation 2002, The Rio + 20 summit in Rio de Janeiro 2012 etc.

The UN Stockholm conference of 1972 which opened the vista for subsequent environmental negotiations was followed by the Brundtland Commission report of 1987.According to Gro Halem Brundtland, the path to development by most industrialized nations was unsustainable, as she observed that terms such as environment and development have been narrowly used (Brundtland Report, 1987).

The foremost UN Conference on Environment and Development (UNCED) was held in Rio de Janeiro in June 1992.Its Agenda 21: A Programme of Action for Sustainable Development which contains the Rio Declaration on Environment and Development, charged nations to adopt a model of sustainable development. This became an agenda for environment and development in the $21 \mathrm{st}$ Century.

Maurice Strong, the Conference Secretary General, at the 1992 summit observed that - the Summit was a "historic moment for humanity" and argued that Agenda 21 had been weakened by compromise however stated that it was still the most comprehensive and, if implemented, effective programme of action ever sanctioned by the international community (UN, 2012).

In 2002 World Summit on Sustainable Development (WSSD) held in Johannesburg, South Africa.It drew attention to the increasing challenges of unsustainable consumption in section III, Changing unsustainable patterns of consumption and production, which reaffirmed the marginalization and elusive stance of Africa on global sustainable development discourse, including the issues of HIV/AIDS, conflicts, insufficient investment, limited market access opportunities and supply side constraints, unsustainable debt burdens, decline in development assistance etc have all affected Africa's development (U N, 2004).

In 2012 , was the Rio +20 summit, The future we want, which was the largest UN negotiation ever organised, and came twenty years after the 1992 Rio Earth summit. Its three pillars included: institutional framework for sustainable development, green economy in the context of sustainable development and poverty eradication

Several leaders across the world were reportedly present including Vladimir Putin (Russia), Mariano Rajoy (Spain), Francaois Hollande (France), Julia Gillard (Australia) and Manmohan Singh (India), Caroline Spelman, environment secretary and Deputy Prime Minister, Nick Clegg represented the UK(The Guardian, UK, 2012).

Table1. Major Global Environmental Negotiations and Resolutions 1970s-2012

\begin{tabular}{|l|l|l|}
\hline Year & Environmental Negotiation & Resolutions \\
\hline 1970 & The Club of Rome and limits to growth & $\begin{array}{l}\text { The Limits to Growth Document } \\
\text { Produced }\end{array}$ \\
\hline 1971 & The Convention on Wetlands & $\begin{array}{l}\text { Global importance of Wetlands adopted } \\
\text { in Ramsar Iran notably Waterfowl } \\
\text { Habitat. }\end{array}$ \\
\hline 1972 & $\begin{array}{l}\text { The UN Conference on the Human Environment held } \\
\text { in Stockholm, Sweden }\end{array}$ & $\begin{array}{l}\text { Adoption of sustainable Environment as a } \\
\text { global concern }\end{array}$ \\
\hline 1972 & $\begin{array}{l}\text { The United Nations Environment Programme (UNEP) } \\
\text { is set up, in Nairobi, Kenya }\end{array}$ & $\begin{array}{l}\text { Novel global awareness on environmental } \\
\text { issues }\end{array}$ \\
\hline 1972 & $\begin{array}{l}\text { The Convention on the Protection of the World } \\
\text { by Dumping of Wastes and other Substances held in } \\
\text { London, and Mexico City, Mexico }\end{array}$ & $\begin{array}{l}\text { Resolution adopted on protection of } \\
\text { World cultural and Natural Heritage }\end{array}$ \\
\hline
\end{tabular}




\begin{tabular}{|c|c|c|}
\hline 1973 & $\begin{array}{l}\text { The 'oil weapon' was first deployed on the world oil } \\
\text { market by the Arab oil exporting countries with } \\
\text { devastating impact, particularly on the developing } \\
\text { countries, including Africa }\end{array}$ & $\begin{array}{l}\text { Prohibition of the use of oil weapon in } \\
\text { the global oil market }\end{array}$ \\
\hline 1973 & $\begin{array}{l}\text { The Convention on the International Trade in } \\
\text { Endangered Species of Wild Fauna and Flora (CITES) } \\
\text { held in Washington, D.C., USA }\end{array}$ & $\begin{array}{l}\text { Resolution adopted on Protection of } \\
\text { Endangered Species of Wild Fauna and } \\
\text { Flora. }\end{array}$ \\
\hline 1973 & $\begin{array}{l}\text { The International Convention for the Prevention of } \\
\text { Pollution from Ships held in London. }\end{array}$ & $\begin{array}{l}\text { Resolution adopted on Prevention of } \\
\text { pollution from ships }\end{array}$ \\
\hline 1975 & $\begin{array}{l}\text { The Convention on Wetlands of International } \\
\text { Importance Especially as Waterfowl Habitat enters into } \\
\text { force }\end{array}$ & $\begin{array}{l}\text { Resolution on Protection and preservation } \\
\text { of the Westlands and its species adopted }\end{array}$ \\
\hline 1975 & $\begin{array}{l}\text { The Convention on the Protection of the World } \\
\text { Cultural and Natural Heritage }\end{array}$ & The resolution enters into force \\
\hline 1975 & $\begin{array}{l}\text { The Convention on the Prevention of Marine Pollution } \\
\text { by Dumping of Wastes and Other Substances }\end{array}$ & $\begin{array}{l}\text { Prohibition of dumping of marine toxic } \\
\text { wastes and protection of marine species } \\
\text { enter into force }\end{array}$ \\
\hline 1976 & $\begin{array}{l}\text { The Convention on the Prohibition of Military or Any } \\
\text { Other Hostile Use of Environmental Modification } \\
\text { Techniques }\end{array}$ & $\begin{array}{l}\text { Prohibition of adoption of hostile use of } \\
\text { marine modification techniques }\end{array}$ \\
\hline 1977 & $\begin{array}{l}\text { The Convention on the Prohibition of Military or Any } \\
\text { Other Hostile Use of Environmental Modification } \\
\text { Techniques is opened for signature in Geneva, } \\
\text { Switzerland in May }\end{array}$ & Resolution adopted \\
\hline 1978 & $\begin{array}{l}\text { The Protocol relating to the International Convention } \\
\text { for the Prevention of Pollution from Ships modifying } \\
\text { provisions, adopted in } 1973 \text {. }\end{array}$ & $\begin{array}{l}\text { The same protocol is adopted in London, } \\
\text { United Kingdom in } 1978\end{array}$ \\
\hline 1978 & $\begin{array}{l}\text { The Convention on the Prohibition of Military or Any } \\
\text { Other Hostile Use of Environmental Modification } \\
\text { Techniques }\end{array}$ & The convention enters into force \\
\hline 1979 & $\begin{array}{l}\text { Protracted negotiations are held at Lancaster House } \\
\text { between the British government and the Patriotic Front. } \\
\text { The talks led to the independence of Zimbabwe in the } \\
\text { following year }\end{array}$ & \\
\hline 1979 & $\begin{array}{l}\text { The Convention on the Conservation of Migratory } \\
\text { Species of Wild Animals held in Bonn, Germany in } \\
\text { June }\end{array}$ & Resolution is adopted \\
\hline 1992 & UNCED Rio de Janeiro & Agenda 21 Adopted \\
\hline 1997 & Rio +5 & Assessment of 1992 negotiations \\
\hline 2000 & Millennium Development Goals & $\begin{array}{l}\text { Development goals and targets for the } \\
\text { new Millennium }\end{array}$ \\
\hline 2002 & World Summit on Sustainable Development (WSSD) & $\begin{array}{l}\text { Johannesburg Plan of Implementation } \\
\text { Adopted }\end{array}$ \\
\hline 2012 & Rio + 20 Summit in Rio de Janeiro & $\begin{array}{l}\text { Environmental sustainability and } \\
\text { development adopted }\end{array}$ \\
\hline 2015 & Sustainable Development Goals & A post 2015 Development Agenda \\
\hline
\end{tabular}

Sources: SADC/IUCN/SARDC (1998 UNEP/Sida (Undated), Author's Update, 2012)

To foster stronger ties on global negotiations on environment and particularly issues of climate change was the establishment of the Intergovernmental Negotiating Committee of the UN Framework Convention on Climate Change in New York in 1990.

Since the UNFCCC entered into force, meeting have been held annually in Conferences of the Parties (COP) to assess progress in dealing with climate change. From 1995 there have been annual global $\mathrm{COP}$ protocols till date.

The subsequent section examines "walking wrong", which on the contrary suggests unsustainable environmental consumption and underscores the failure of the industrialized societies of the global North to wholly commit to the resolutions of the global environmental negotiations.

\section{WALking Wrong: The Global UnSUStainable EnVironmental Consumption}

Despite impressive records from the robust environmental negotiations, a number of events point to walking wrong. In 1991 at the concluding negotiations on the UN Framework Convention on Climate 
Change, industrialized countries acceded to reducing their $\mathrm{CO}^{2}$ emissions to the 1990 levels by the year 2000. On the contrary, under intense pressure from the Bush Administration, the emission commitments in the Convention were not legally-binding.

The FCCC was opened for signature at the Earth Summit, held in Rio de Janeiro in June 1992, where 154 country representatives signed in (FCCC,1993). It has often been argued that many communities across the globe have been exposed to images of opulent, consumptive Western lifestyles and come to covet those life-styles and view their own, more modest lifestyles as inferior (Davidson and Hatt, et al.; 2005:230). Pierre-Louis, (2012:2) observes that in 1992, at the very first United Nations Conference on Environment and Development (UNCED), former United States President George H.W. Bush declared that the American way of life is not negotiable.

Pierre-Louis, (2012:2) contends that it was his response to the crowd of world leaders, environmental activists, and social change agents, assembled before him in Rio de Janeiro, Brazil, who had come upon the collective realization that the earth's ecology and human survival was threatened as a result of environmental resource use.

Peter Jamison (2012) reports that events in the past decade, suggest increasing opposition to Agenda 21 in the United States at all levels of government. He points out that the Republican National Committee adopted a resolution opposed to Agenda 21, they argue that the U.N. Agenda 21 which is erosive of American sovereignty.

In 1997, the UN General Assembly convoked the Rio+5 summit to assess progress five years after the previous summit which had discouraging conclusion in most critical sectors notably land, climate change, forests, freshwater, biodiversity etc. Conditions were no better as they were in 1992 or had worsened (Hinrichsen et al; 2002).

In the late 1980s, Lester Brown came up with a study on the world's arable land. According to Brown (1989:2-3), 77\% of the world's arable land had already been at least moderately degraded. One third had lost at least a quarter of its productivity. The amount of available arable land is important, of course, since it at least partly determines the amount of food crops that can be grown by one estimate, soil erosion is responsible for \$ 1 billion in lost crops annually (Brown, 1989:60; Newton, 1992).

Key provisions of Agenda 21 have been marginalized by the high income countries (Stern,1997; Hobson,2003;Schor,2005).After the COP 3 held in Kyoto in 1997, where the Kyoto Protocol on Climate Change as adopted. The United States was meant to decrease its total emissions on the average of 7\% below 1990 levels; neither the Clinton nor the Bush administration sent the protocol to Congress for ratification. The Bush administration explicitly rejected the protocol in 2001(UNFCCC, 1993).

Unsustainable Consumption of the global North with its power relations and domination has impacts on access to environmental goods and services "a question of equity; decision process related to environment: How decisions about natural resources and ecosystems have been taken.

How to stimulate environmental equity etc. For instance Davidson and Hatt, (2005:230)argued that the Western individualized, mass consumption has become a hegemonic ideal the world over, with devastating ecological results .Thus, environmental negotiations have been feeble to redirect this hegemony.

American economist Lester Thurow(1992:226) argued that if the world's population had the productivity of the Swiss, the consumption habits of the Chinese, the egalitarian instincts of the Swedes and the social discipline of the Japanese, then the planet could support many times its current population without excessive pollution or deprivation for any-one. On the other hand if the world had the productivity of Chad, consumption patterns of the United States, egalitarian instincts of India, social discipline of Yugoslavia, the world and its population would not fare better. Thurow (1992:226), stated that on the contrary, most humans seem to align in the America-India-ChadYugoslavia category.

Ecologist, Paul Driessen in his seminal book "Eco-Imperialism: Green Power, Black Death" , chronicles the increasing environmental challenges arising from wealthy, left-leaning Americans and Europeans and imposition of their world views on billions of poor, desperate Africans, Asians and 
Latin Americans. This he demonstrates violates most of their basic human rights, and denies them economic opportunities, the chance for better lives, and the right to rid their countries of diseases that were vanquished long ago in the U.S. and Europe (Driessen, 2003).

For instance on corporate social responsibilities (CSR) of multinational corporations, Driessen argued that UK based British Petroleum has been one of the most environmental polluting company globally. Stating that the company fixed costly solar panels on 200 of its 17,000 service stations and, over a two period spent nearly \$ 200 million on a barrage of clever news releases and newspaper, television and ads on the side of buildings. All turned the same basic messages: We protect the environment vigorously support the Kyoto global warming treaty and devote past sums to wind and solar energy by the way we still produce petroleum but (But we produce it more responsibly than our competitors) (Dressen,2003).

In a survey on Japanese consumers, Hiroyuki Nitto and Junichi Shiozaki discovered the influence of globalization on consumption patterns in China with increase in the ratio of people travelling overseas in recent decades from 8percent in 1997 to 26.5 percent in 2000.Moreover the average ratio for all Japanese who reported having lived abroad for one month or longer reached 4. 3percent in 2000 (Nitto and Shiozakki, 2001:2).

Major delays in ratification of global negotiations by the industrialized nations was also part of the issues that rendered most negotiations ineffectual. For instance, in December 2002, Canada after a -3month national debate ratified the Kyoto Protocol five years after the Protocol open for signature, and after long negotiations (UN,2012). While Russia ratified the protocol on February 16, 2005, as the Kyoto Protocol became international law after Russian ratification pushed the emissions of ratified Annex 1 countries over the 55 per cent mark.

Note that it needs seven years since the signature open in COP 3 , and seven years to go the conclusion of first commitment period (UN ,2012). In 2000, the Cop 6 which held in The Hague failed, primarily because of controversy surrounding "a high-level negotiation over the major political issues" involving US and also rejection of compromise positions by some EU countries spearheaded by Denmark and Germany beyond compromises reached between the United States and other EU countries, notably the United Kingdom (UN,2012).

After the failure of the Copenhagen negotiations of 2009 to resolve global climate change issues was the 2015 Paris climate change agreement which had about leaders of 196 nations including the US, China, India, Russia etc in attendance. Resolutions were adopted to improve the persistent climate change issues since the 1992 earth summit.

Environmental transformation however has been minimal. In an era of global environmental negotiations, there has been persistence of environmental disaster globally. In Europe, America, Latin America, Asia and Africa. There are also human induced disasters like the gas flaring, acid rains, oil spill in Niger Delta region of Nigeria by oil multinationals. These have devastating effects on both human beings and the natural environment.

Ecologically, there have been droughts in parts of East and Southern Africa, also the 2012 severe floods in the coastal Niger Delta gave rise to internal displacement and migration (Amadi, 2013). Others included the floods in Kenya between 1997 and 1998, Mozambique in 2000. Beyond causing an emergency relief, several lives were lost while others were internally displaced (UNEP, 2002). In the Kenyan crisis, the cost alone stood at about US\$1 billion (UNEP, 2002). In Asia, there have been tsunamis which struck around Okushiri Island of Hokkaid on July 12, 1993,there was the 2004 Indian Ocean tsunami with over 230,000 people killed in 14 countries bordering the Indian Ocean. The Haiti earthquakes of 2012, the US Atlantic hurricanes Andrew 1992, Katrina 2005, Irene 2011, Sandy flood, 2012 and the 2013 Tonardo etc are evidence of environmental disaster and challenges.

There are similar challenges posed by economic activities of the industrialized West, specifically the extractive industry. First, it is important to remember that all manufactured goods have environmental effects associated with their production and in some cases, consumption (Schor, 2005:2).

In oil exploitation and exploration in most coastal regions (as earlier discussed) divergent environmental hazards ensue which reduces life expectancy and practically makes the environment uninhabitable. Hatt, et al; (2005:16) amply demonstrate the intensity of consumption of the environment by the developed countries of Europe and America. 
According to many critical accounts of ecological disruption, countries in North America and Western Europe have already consumed sustainability for others by appropriating the bulk of the world's resources to themselves(Davidson and Hatt et al;2005).

Paul C. Stern provides one of the most useful analyses on the significance of environment consumption. According to Stern (1997:20), consumption is environmentally important to the extent that it makes materials or energy less available for future use, moves a biophysical system towards a different state or through its effects on those systems, threatens human health, welfare or other things people value.

Growing pollution by the global North, equally has health implications this does not limit pollution to the countries of the north alone in China as well as India there are cases of massive pollution. However the intensity has been high in the North (Hinrichsen et al;2002).

In virtually all countries, studies identify health problems linked to environmental contamination (Hinrichsen, et al; 2002). Paul and Anne Ehrlich have estimated that one person in a developed country produces as much pollution as a hundred people in an underdeveloped country( Worzel, 1994:184).

In developing countries today the old killers are still around tuberculosis, malaria, and diarrheal diseases, among others and now HIV/AIDS,Ebola and Zika virus. But joining these as important causes of death and ill health are cancers and chronic diseases caused by industrial and agricultural chemicals and other pollutants in the atmosphere, soil, and water (Hinrichsen et al; 2002) .

Both Worzel (1994) and Newton (1992) are of the view that the developed countries use the vast majority of the currently developed resources, and produce the vast majority of pollution. Paul and Anne Ehrlrich (1991) gave an equation to describe the impact humanity has on the planet: I=PxAx T Where I=impact or effect, $\mathrm{P}=$ population; $\mathrm{A}=$ affluence, or percapita consumption; and $\mathrm{T}=$ Technology, or the effect of technology in producing each unit of affluence (Ehrlrich and Ehrlich 1991:7; Worzel, 1994:184).

What this means is that 27 million Canadians living in an affluent society and employing a significant amount of technology to maintain it will do more damage to the ecology than 270 million people living in mud huts and herding goats in Africa (Worzel, 1994:184).

The facts as presented in the Economist in 1991confirmed this; The average person in a developing country uses the equivalent of one or two barrels of oil a year of fuel (apart from what is scavenged directly from forests and fields):the average European or Japanese, the equivalent of between ten and 30 barrels a year; the average American,40 barrels ( Worzel, 1994:184).

Persistent Organic Pollutants (POPs) which are organic compounds that have long lives in the environment and undergo physical, chemical, and biological changes over time, occurs in several ways in foods, mostly as pesticide residues; occupationally, as among farm workers who spray pesticides on crops; and through accidents, including leaks in indoor storage areas( Hinrichsen et al;2002 ).

Moreover population contributes to pollution problems primarily when people are crowded together in urban areas. Thus the combination of population and pollution are likely to be most serious in the world's larger urban areas such as Mexico city, Sao Paulo, New York and London (Newton, 1992:94).

Kaplan (1994:55) argues on the imminent dangers of population growth especially in the poor countries like Africa. The challenges of falling human fertility have been explored (Hinrichsen et al;2002 ).

The World Health Organization (WHO) estimates that about 700,000 deaths annually could be prevented in developing countries if three major atmospheric pollutants carbon monoxide, suspended particulate matter, and lead were brought down to safer levels ( Hinrichsen, et al;2002 ).

Urbanization, modernization and globalization are also contributory factors to global unsustainable lifestyle (Amadi,et al;2016). The urban expansionist theorists have been wary of its effects on the environment. Hagedorn, et al;(1980), argue on the possibilities of de-urbanization and deindustrialization arising from unsustainable consumption pattern of the Western societies. They 
contend that it is now all too clear that this consumption cannot continue indefinitely. Supplies are finite .In fact, if urban industrialized countries do not soon develop more energy-efficient machines and increasingly make use of alternative energy sources (like hydro, solar atomic power), the process of de-urbanization and deindustrialization will begin in Western societies (Hagedorn, et al; 1980:527).

Fresh water commodification fostered by neo-liberal capitalist drive reduces water to its use value to humans (Swatuk, 2008). According to the World Commission on Water for the 21st Century, more than half of the world's major rivers are so depleted and polluted that they endanger human health and poison surrounding ecosystems.

In many large cities in the developing world the drinking water supply is contaminated. Only half of Southeast Asia's 550 million people have access to safe drinking water. The supply of freshwater on earth is finite. Thus, as population grows, there is less water per capita ( Hinrichsen et al;2002).

In the United States, private water delivery systems now make more than $\$ 80$ billion in annual revenues (Speake and Gismondi, 2005:63).Companies notably coca kola contribute to global water shortage while commodification is intensified by global water corporations such as DuPont. Similarly, a French corporation, Lynnaise des Eaux is the world's largest water corporation giving rise to commodification and fresh water depletion (Speake and Gismondi, 2005:63).

In the early 1990s, experts began to express greater concern about one specific form of environmental damage: Changes in the atmosphere. Evidence began to accumulate that human activities were starting to deplete the ozone layer in the earth's stratosphere and to increase the atmosphere's annual average temperatures (the green-house effect) Newton, 1992:96).Data on these two effects were both questionable and incomplete but more and more authorities thought that population growth might be a critical factor in producing potentially dangerous changes in the atmosphere (Newton, 1992:96).

Maurice Strong is cited as saying that it could cost as much as \$ 600 billion a year to lower carbon dioxide emissions (Worzel, 1994:181).

In 1990 atmospheric concentrations of carbon dioxide the main climate changing gas-were measured at about 355 parts per million. In 1997 concentrations were measured at about 364 parts per million. Since 1950 carbon dioxide emissions have increased fourfold (Hinrichsen, et al; 2002).

Thurow(1992:226 )argues that issues like global warming are not going to be easy to solve because of long-tail problems(The $\mathrm{CO}^{2}$ discharged today will be affecting the world's climate fifty years from now).By the time it is absolutely clear that global warming is occurring, it will be too late to do anything about it.

The fast warming up of water in the tropics have been reported by the US National Oceanic and Atmospheric Administration (NOAA) as tropical oceans retain heat more readily than other areas(Hinrichsen, et al;2002).

Energy is central to most other ecological concerns. We use energy to do almost everything, but when we use it inefficiently it does enormous damage to our ecology. Interestingly, the key to energy is not just the production of it. Equally important is storing it and having it available when and where we need it (Worzel, 1994:188).For instance, in the UNDP/World Bank Energy Sector Management Assistance Programme in 2001 reported the high incidence of gs flaring in Nigeria accounting for about 20\% of the global gas flaring, the World Bank 2005 report shows about $75 \%$ incidence of gas flaring in Nigeria (Gogo, 2011:3). Nonetheless, most industrialized countries use energy more efficiently than developing countries (Hinrichsen, et al; 2002).

Globally animal species are fast diminishing from hunting through pollution, destruction of the natural habitats and the ecosystem. Conservation of wild life has not been effective in developing countries such as Africa lions ,Tigers, Elephants, Pythons are fast disappearing various species of mushroom found in eastern Nigeria are gradually extinct, snails ,periwinkles and assorted sea foods and marine habitats are fast diminishing. According to Michael Klare (1995:235), the trends of the past 20 years show an accelerated destruction of coastal marine habitats ,increases in coastal pollution ,and in many areas, a shrinking of the marine fish catch.

In 1990, the global fish catch decline for the first time in 13 years-a result of over fishing, coastal habitat destruction and water pollution (Klare, 1995: 235).

Hinrichsen, et al; (2002)argue that in most coastal cities there are evidence of duming of untreated wates into the seas which results in virtual cesspools associated with pollution that threatens marine 
life.They cited the experience of the Gulf of Mexico which they termed an environmental"dead zone" characterized with agricultural and industrial pollution.

According to FAO, 69\% of the world's commercial marine fish stocks are" fully exploited, overfished, depleted, or slowly recovering"notably tuna, cod and haddock, have dropped by one-quarter since 1970 (Hinrichsen, et al; 2002).

On deforestation, there is decline in forest cover across the world. In Africa this accounts for decline in food and agricultural produce (Hinrichsen, et al; 2002).

Soil loss is another problem affecting environmental sustainability. A World Bank report suggested that the incidence of soil loss was 10 times higher on forest lands were farming is experienced unlike undisturbed forests (Hinrichsen, et al; 2002).

Between June 10- 17, 2011 the First Africa Drylands Week and World Day to Combat Desertification held in Dakar, Senegal. The challenges remains perennial in most African countries.

Although globally there is a decline in deforestation, however deforestation has persisted in Africa and South America, as reported by the FAO's 2010 Global Forests Resource Assessment (Amadi and Ogonor,2015). Kaplan (1999:58)recounts that the environment should be understood as the national security issue of the twenty first century.

In the United Nations Population fund report for 1998, Dr.Nafis Sadik claims that the spread of the desert is one reason for Africa's failure to match overall population growth with food Production (Newton,1992:10;Sadik, 1991:8).

There is Rising Sea Levels. Globally, this has been perverse inmost coastal regions, according to the 1990 report of the international Panel on Climate Change( IPCC ), sea levels might rise by 30 to 110 centimetres by the year 2100 , affecting 360 , 000kilometers of coastal line.

The resurgent environmental challenges taking place in the era of global environmental negotiations point to the urgency of novel collaborative efforts by all key actors to check unsustainable environmental resource consumption.

\section{CONCLUSION}

This study has revealed that despite a brief chronology of global environmental summits and conventions from the 1970s to 2012 and in particular the post 2015 Paris climate change convention, there have been incidence of environmental disaster and similar problems pointedly arising from unsustainable consumption of the industrialized societies.

The central issues has been the fact that most of the resolutions at the negotiations are not bidding on members despite the fact that most of the development paths of the high income societies fall short of environmental sustainability (Brundtland Report, 1987). To get most of these challenges right have been difficult because of the economic interest of the industrialized societies. This has a grave consequence for the ecology.

Environmental negotiation at one point seems to be an emerging paradigm, in another it appears to decant into uncertainties and somewhat incapacitated to transform the environment. It has not devised mechanisms for compliance and global enforcement standards, neither has it provided boundary and limits to environmental consumption, ecological justice and global equality.

It has been unable to meet the environmental needs of the poor nations of the world in practice. Despite the claims of the Johannesburg Plan of Implementation, poverty and HIV/AIDS remains high in Africa (World Bank, 2015). The green environment, eco efficiency which should guide global manufacturing is not prioritized; equally gender issues are merely highlighted but not operationalized.

According to Thurow,(1992), one of the major problems needing cooperative action is that of preserving and improving the global environment. When the post-World War II economy was designed, environmentalism was not an issue. But today institutions need to be built to deal with global environmental problems.

In the context of novel modalities to transform prevalent global environmental negotiations to enforcement, Davenport (2006) provides some important insights in understanding the patterns of 
relationship between the United States and its negotiating countries and the attendant effects on environmental treaty. She analyzed three salient environmental problems notably deforestation, climate change and ozone protection, and underscored the less commitment of the US in international environmental negotiation using a cost benefit framework. She argued that novel collaboration is expedient.

Despite the global negotiations, current policies have been ineffectual in providing a blue print environmental justice and equity principles. Sustainable development discourse is yet to break the ruling development paradigm.

The strategies suggested include; empowerment of marginalized groups in environmental decisions notably the volatile regions of the world like the coastal Niger Delta region of Nigeria. Little emphasis is laid on how high income countries can channel their resources to better environmental perception which is fundamental to sustainability.

Conversely, ecological modernization principles seem to have been favored in global environmental negotiations, relying largely on technological solutions. Focusing on environmental efficiency through institutionalization of optimization of environmental use rather than unsustainable and inequitable environmental use is suggested.

The post 2015 Paris climate change summit has not shown novel commitment to ecological justice by the industrialized societies. Sustainable development agenda should be enlarged and re-tooled to focus on results of sustainable environmental consumption, scrutinizing how countries have adopted strategic approaches to ameliorate deleterious environmental use not what countries should do for sustainable consumption. Global environmental accounting index should be provided which should focus on what countries have done to protect the environment including plant and animal species.

There should be a blue print on common enforceable environmental standards with the G8 countries on the lead which should be an evaluation of commitment to environmental sustainability. The G8 countries should as a matter of expediency cooperate with the rest of the world in making environmental negotiations bidding and enforceable.

As a matter of environmental justice, COP needs viable enforcement mechanisms such as sanctions on countries who fall short of stipulated standards. Parties to COP should now adopt green global policies (GGPs).

Future negotiation agenda should explore themes such as global eco- efficiency index at country, regional and global levels, ecological footprints, greening, eco labelling and of course mitigation of climate change adaptation and vulnerability into various facets of development planning . The role of environmental stakeholders-including NGOs, the civil society, humanitarian organizations, world Leaders, multi and bilateral organizations is important, they should meaningfully engage on environmental negotiation.

Corporate Social Responsibility (CSR) by multinational oil companies and similar environmental related companies should now be broadened with Green Corporate Social Responsibility (GCSR) as a specific strand aimed at environmental consciousness.

National interest should be given up for global environmental sustainability. Dealing with the problem of exclusion of the poor societies in global environmental resolutions through a new social inclusion agenda is critical to incorporate the poor vulnerable societies in particular women who are vulnerable, the physically challenged, those living with HIV/AIDS etc, should be prioritized.

Rearticulating strategies for individual and Institutional capacity building on the core relevance of amelioration of unsustainable consumption with understanding of the tenets of eco -efficiency, resourceful environmental choices, building of alliances and promotion of partnerships through a grassroots approach and collective response to down line environmental negotiation discourses, unlike the prevailing top bottom approach. The environment as basis for sustainability should be a common global concern from the grassroots level. Since 1972 and the aftermath of the publication of The Limits to Growth, the word sustainability has become a buzz word. Environmental resources are yet to be predicated on the recognition that it could be depleted, the current rate of unsustainable environmental consumption continues unchecked. 
Process to results strategy is critical as the question is no longer environmental negotiations (process) rather how the affluent societies have reduced ozone layer depletion, green house emission etc (results).Global environmental negotiations should as a matter of planetary necessity move away from environmental policy formulation or negotiation to environmental policy implementation or enforcement.

Results should be the key driving factor to environmental negotiations. The much criticisms faced by agenda 21 is its non- adherence by the affluent North. Global environmental negotiation is no longer news, key modifications should be on enforcement. Future environmental negotiations should prioritize and enforce realities of everyday environmental challenges.

In five decades of its repeated failures, a paradigm shift to results is expedient. We propose a results based global environmental negotiation, which should demonstrate periodic sustainable environmental progress of nations, to be time bound, measurable, equitable, pro-poor and aimed to achieve long/medium term environmental sustainability that is people centred (participatory). Beyond anthropogenic perspectives, the strategy will address both the human (atmosphere) and non- human environment.

\section{ACKNOWLEDGEMENTS}

Preliminary version of this paper was presented in an International Conference on Negotiation: Dispute Resolution and Conflict Management in a Changing World April 10-12, 2014 at Kennesaw State University, Kennesaw (Atlanta Suburb), Georgia, USA

The authors are grateful to the anonymous reviewers.

\section{REFERENCES}

[1] Adibe, E, (1994). "Weak States and The Emerging Taxonomy of Security in World Politics", FUTURES, pp496.

[2] Amadi L. (2012). Africa: Beyond the "new" dependency: A political economy African Journal of Political Science and International Relations Vol. 6(8), pp. 191-203.

[3] Amadi.L(2013). Climate Change, Peasantry and Rural Food Production Decline in the Niger Delta Region: A case of the 2012 flood disaster. Journal of Agricultural and Crop Research . Vol. 1(6), pp. xxx-xxx . Research Paper.

[4] Amadi L and Ogonor M (2015). Climate Change, Environmental Security and Displacement in Nigeria : Experience from the Niger Delta, African Journal of Environmental Science and Technology Vol (9)1.pp53-64.

[5] Brown, L; (1989). "Grain Drain”, The Futurist, July/August 1989,pp.9-16

[6] Carson R (1962). Silent Spring Boston : Houghton Mifflin

[7] Collier ,P;(2010). The Plundered Planet. Why We Must--and How We Can--Manage Nature for Global Prosperity Oxford Press.

[8] Davenport. D, (2006).Global Environmental Negotiations and US Interests Palgrave Macmillan 288 pages

[9] Davidson, D.\& Hatt. K, et al ;(2005). Consuming Sustainability Critical Social Analysis of Ecological Change.Canada: Fernwood publishing.

[10] Dressen. P; (2003). "Eco-Imperialism: Green Power, Black Death. Free Enterprise Press: elleview, WA.

[11] Ehrlich P and Ehrlich A.(1991).Healing the Planet. Mass :Addison Wesley

[12] Food and Agriculture Organization (FAO) (2003) the State of the World's Forests. Oxford Press

[13] Goodland R. (1992). "Ecological Limits: The evidence that humanity is reaching the limits of what the Earth can sustain". Context Institute available http://www.co ntext.org/iclib/ic36/g oodland retrieved 15th Nov 2012.

[14] Hardin G. (1968). The Tragedy of the Commons. Science Vol. 162 no. 3859 pp. 1243-1248

[15] Hatt K, Davidson D and Lock I "Power and Sustainability" in: Davidson, D. \& Hatt. K, et al; (2005).Consuming Sustainability Critical social Analysis of Ecological Change. Canada: Fernwood publishing. 
[16] Hegedorn, .R (ed),etal (1980).Sociology Holt, Riehart and Winston of Canada Limited

[17] Hinrichsen, D., Salem,R., and Blackburn, R.(2002). Meeting the Urban Challenge. Population Reports, Series M,No. 16. Baltimore, the Johns Hopkins Bloomberg School of Public Health, Population Information Program.

[18] Hobson, K.(2003).Consumption, Environmental Sustainability and Human Geography in Australia: A Missing Research Agenda?.Australian Geography Studies.41(2)148-155

[19] Holsti, O. (1969). Content Analysis for the Social Sciences and Humanities. Reading, MA: Addison-Wesley

[20] Homer- Dixon (1991). "On the Threshold: Environmental Changes as Causes of Acute Conflict "International Security Trudeau Centre for Peace and Conflict Studies,University of Toronto International Security, Vol. 16, No. 2.Baltimore, Maryland 21202-4012, USA Volume XXVIII, Number 3 Series M, Number 15,2002.

[21] Jamison P (2012). "Fears of Agenda 21 go mainstream in the Republican Party platform". Tampa Bay Times. Available atwww.tampabay.com/news/politics/national/article.Retrieved 20/6/2016.

[22] Kaplan .R, (1994). The Coming Anarchy: How security crime, overpopulation, tribalism and disease are rapidly destroying the social fabric of our planetl, The Atlantic Monthly February pp 49.

[23] Klare. M, (1996). “Redefining Security: The New Global Schisms”. Current History, November.

[24] Krippendorff, K. (1980). Content Analysis: An Introduction to Its Methodology. Newbury Park, CA: Sage.

[25] Krippendorff, K. (1989). Content analysis. In E. Barnouw, G. Gerbner, W. Schramm, T. L. Worth, \& L. Gross (Eds.), International encyclopaedia of communication (Vol. 1, pp. 403-407). New York, NY: Oxford University Press. Retrieved from http://repository. upenn.edu/asc_papers/226

[26] Lasswell, H (1948). Power and Personality. New York, NY

[27] Ladidi Y; (2011). Nigeria: Tackling Deforestation Problems, Daily Trust 3 June 2011 Available at http://www.afrol.com/Categories/Environment/backgr_deforestation.htm andhttp://www. fore sts. org /africa/retrieved 9/11/2012

[28] Newton, D. (1992) Population Too Many People? Enslow Publishers, Inc, Bloy St. and Ramsy Ave. Hillside, NJ 07205, USA

[29] Nitto. H and Shiozakki.J, (2001). "Changing Consumption Patterns in the 21st Century". Normura Research Institute. NRI papers No.24.

[30] Pierre-Louis K "Hacking into the Green Economy" Urban Times online magazine, 12th Feb 2012. Available at: http://urbantimes.co/2012/02/green-economy retrieved 15/11/2012

[31] Sadik.N (1991).'The State of the World Population” New York: United Nations Population Fund.

[32] Schor, J.(2005)Prices and quantities: Unsustainable consumption and the global economy, Ecological Economics 55 (2005) 309- 320

[33] Sheldrick D (1977) the Orphans of Tsavo William Collins Sons \& Co Ltd Glasgow.

[34] Spearke S and Gismondi, "Water: A Human Right in: Davidson, D. \& Hatt. K, et al; (2005) Consuming Sustainability Critical Social Analysis of Ecological Change.Canada: Fernwood publishing.

[35] Stern P. (1997). Environmentally Significant Consumption. Research Directions National Academy Press Washington DC.

[36] Stemler, S and Bebell, D. (1998). An Empirical Approach to Understanding and analyzing the mission statements of selected Educational Institutions. Paper presented at the annual meeting of the New England Educational Research Organization. Portsmouth, New Hampshire. Available: ERIC Doc No. ED 442202.

[37] Suhrke. A (1996).Environmental change, migration and conflict: A lethal feedback dynamics?in Chester A. Crocker et al. (eds.): Managing global chaos: international cooperation in issues of displacement. Washington D.C: Carnegie Endowment for International Peace pp. 113-127. 
[38] Swatuk.L, (2008). "Panel : Water Ethics and Commodification of Freshwater Resources", .htt:// www. International waterlaw .org/ bibliography /articles/ Ethics /Common_Grounds_Symposi um/ Panel_One.pdf.

[39] Thurkur.R; (2006) the Chemical Weapons Convention: Implementation, Challenges, Opportunities pp 190.

[40] Thurow. L; (1992) the Coming Economic Battle Among Japan America, and Europe. William Marrow and Company Inc. 1350 Avenue of Americas, New York.

[41] Transparancy International (2014) Keep corruption out to halt climate Available at changehttp://www.transparency.org/news/feature/keep_corruption_out_to_halt_climate_change. Retrieved 10/10/2015.

[42] Newton, D; (1992).Population Too Many People? Enslow Publishers, Inc, Bloy St. And Ramsy Ave. Hillside, NJ 07205, USA.

[43] United Nations Environment Program (2002) Africa Environment Outlook, past, present and future perspectives, 2002. Available at www.unep.Org /dewa/africa/.../Policy_Analys is_ Guidelines

[44] United Nations Framework Convention on Climate Change (1993) Framework Convention on Climate Change (UNFCCC or FCCCC) Available at http://australia.wikia.com/wiki/Unit ed N ations_Framework_Convention_on_Climate_Change.Retrieved 20/6/2016

[45] UN,(1998)Consumerism: Human Development Report 1998 Overview, Bulletin

[46] United Nations, Economic and Social Affairs Department (2004) Changing unsustainable patterns of consumption and production.

[47] UN, World Commission on Environment and Development (1987)“Our Common Future”. Brundtland Report, Oxford

[48] United Nations Commission for Environment and Development (UNCED)(1992) Agenda 21: Rio Declaration, Rio de Janeiro, Oxford Press

[49] UN, (2012) History of Sustainable Development Rio +20 Available at www.uncsd.org/history. $\mathrm{Html}$ retrieved 15/11/2012.

[50] UN (2015) United Nations Treaty Collection Available at https://treaties.un.org /Pages/overv iew.aspx?path=overview/definition/page1_en.xml\#conventions.Retrieved 20/6/2016.

[51] Weber, R. (1990). Basic Content Analysis, 2nd ed. Newbury Park, CA.

[52] White, L (1967). The historical roots of our ecological crisis. Science 155. pp. 1203-1207

[53] Wolf Jutta "Africa Addresses Desertification and Biodiversity Loss" 2011 IDN In Depth News| Analysis That Matters available at http: //www .indepthnews.net/area2. php?key=PE,retrieved $15 / 11 / 2012$.

[54] World Bank. World development report (1992): Development and the Environment. Oxford, Oxford University Press.

[55] Worzel .R; (1994) Facing the Future; The Seven Forces Revolutionalizing Our Lives, Stoddart Publishing Co.Limited,34 Lesmill Road, Toronto Canada. 